\title{
BED SCOUR IN CURVED OPEN CHANNFLS
}

\author{
$\underline{B y}$ \\ Atef Abdel -Hameed EI-Saiad \\ Associate Professor at Water and Water Structures Eng. Dept \\ Faculty of Eng., Zagazig Univ., Egypt.
}

\begin{abstract}
The mechanics of flow in a curved alluvial channel has some distinct characteristics that are absent in a straight alluvial channel. The forces governing the flow are different in nature. The flow is asymmetrical, and an interaction between the secondary current and primary flow produces a spiral flow pattern affecting the transport of secliments. It is generally assumed that the governing forces in a bend flow are the centrifugal forces due to the vertical nonuniformity of the velocity profile combined with the flow curvature, the shear stresses, and the radial pressure gradients caused by transverse inclination of the water isurface. The balance between the gnverning forces tends to produce a helical flow pattern in the bend and a tilting of the channel bed, with an increase in the depth near the outer (concave) bank. As a result, the outer bank is often undermined and eroded. This experimental study have been made to relate these features to mean flow characteristics. The effect of curvilinear flow on scour in two opposite successive bends of central angle $133.29^{\circ}$, the bend radius at center line, $\mathrm{r}_{\mathrm{c}}=20,22.5$, and $25 \mathrm{~cm}$, and the bend width $\mathrm{B}=10,15$ and $20 \mathrm{~cm}$. are discussed in this study. Empirical equations have been developed for estimating the maximum scour depth for the two opposite successive bends, the first is called upstream bend and the second is the downstream one.
\end{abstract}

\section{INTRODUCTION}

The behavior of curvilinear flow in curved open channels and rivers has been studied for many years because of its importance in channels and rivers morphology. The movement of sediment plays an important role in deciding the stable geometry of the bed at river bends. The bed load will have a tendency to move towards the inner bank on account of secondary flow. This radial movement of the bed load causes scour near the outer bank (concave bank) and deposition near the inner bank (convex bank). Many investigators have attempted to explain the bed deformation in meandering rivers. The process of scour and deposition at bends in alluvial streams are reviewed in the following paragraph.

Yen (1970) studied the bed topography effect on flow in a meander. Approximate theoretical analysis indiçates that the fully developed, curved channel flow, the transverse slope at a given point on the stabilized bed is directly proportional to the parameter which characterizes the relative importance of fluid inertia against the gravity acting on a particle, moving along the bed. The fact of proportionality lumps the effects of drag, lift, longitudinal bed slope, and friction between the particle and the bed. He found that the bed topography is a function of width-depth ratio, the Froude number and 
the ratio of particle fall velocity to the mean flow velocity. (1974). Studied the flow and bed topography in channel bends. They analyzed movement of sediment in bends, and employed sediment continuity and transport formulas to predict equilibrium topography. They studied the drag force effect on the bed slope in longitudinal and transverse directions. They studied the scour and deposition pattern at a $90^{\circ}$ bend.

Kikkawa et al (1976) studied the characteristics of flow and the bed topography in a curved open channel. $\mathrm{He}$ investigated the change of bed profile with time and the stable bed profile. He studied the segregation phenomenon in the curved open channel and found that when the bed load is transported toward the inside, it is reasonable to suppose that smaller size sand particles are conveyed more often than the larger particles, because the smaller ones are more easily transported.

Carson, M. A., and LaPointe,M. F., (1983) investigated a reach of the Rouge River, and found that even though the intensity of near-bank primary velocity may be the main control on erosion. Erosion at the outer bank near bend entrances can occur in response to high bank shear stresses associated with the formation of concentrated helical flow.

Struiksma et al (1985) studied the bed deformation in curved alluvial channels. The main result of his study is that it leads to estimates of the wave length and bed oscillation damping rates, however, good agreement with measured data can only be obtained by using a calibration factor in the sediment transport direction equation. From the analysis the conclusion is drawn that the point bar height and pool depth in bends can not be predicted solely from local conditions, A significant part of the lateral bed slope is due to an overshoot effect induced by the redistribution of the water and sediment motion in the first part of the bend.

Odgaard (1987) assumed that the bed particles are stable in both longitudinal and radial directions but are at incipient motion condition in the longitudinal direction. Such as analysis also led to the conclusion that the lateral slope is proportional to $h_{d} / r_{\mathfrak{c}}$.

Ikeda et al. (1987) found that sorting of bed material in bends could reduce the maximum equilibrium scour depth as dramatically as $30-40 \%$ in the fully developed region of uniformly curved bends.

Yen et al. (1995) conducted five experiments in a laboratory channel bend of central angle $180^{\circ}, r_{c}=4.0 \mathrm{~m}$ and $\mathrm{B}=1.0 \mathrm{~m}$. The bend was connected with upstream and downstream straight reach and they concluded that, the bed deformation and transverse sorting of sediment become significant beginning around section $30^{\circ}$ and $15^{\circ}$, respectively. Also, the maximum deposition height takes place between sections $75^{\circ}$ and $90^{\circ}$, and the maximum scour depth occurs between sections $165^{\circ}$ and $180^{\circ}$.

Kawai and Julien (1996) carried theoretical and experimental study for bed deformation in a bend with attention focused on point bar formation and possible scour near the inner bank in the case of coarse- grained point bars. They found that the maximum scour depth is observed at a bend angle $\alpha=60^{\circ}$ near the outer bank and the bed deformation near the outer bank and the inner bank from bend angle $0 \prec \alpha \prec 40^{\circ}$.

\section{DIMENTIONAL ANALYSIS}

Using the principals of the dimensional analysis, the different variables affecting 
the relative scour depth can be listed in the following equation,

$\frac{\mathrm{d}_{\mathrm{s}}}{\mathrm{H}_{\mathrm{c}}}=\phi\left(\frac{\mathrm{B}}{\mathrm{H}_{\mathrm{c}}}, \frac{\mathrm{r}_{\mathrm{c}}}{\mathrm{H}_{\mathrm{c}}}, \frac{\mathrm{d}_{50}}{\mathrm{H}_{\mathrm{c}}}, \mathrm{F}_{\mathrm{c}}, \frac{\mathrm{t}}{\mathrm{t}_{\mathrm{o}}}\right)$

Where,

$\mathrm{B}$ : the channel width

$d_{s}$ : the maximum depth of scour,

$\mathrm{d}_{50}$ : the mean diameter of bed material

$\mathrm{H}_{\mathrm{c}}$ : water depth at center line of the curved channel

$r_{c}$ : radius of curved channel at the center line

$t:$ time of scour.

$t_{0}$ : time of ultimate scour depth

$\mathrm{F}_{\mathrm{c}}$ : the Froude number at the center line

$$
\left(=\mathrm{V} / \sqrt{\mathrm{gH}_{\mathrm{c}}}\right)
$$

$\mathrm{V}:$ the mean velocity.

$\mathrm{g}$ : gravitational acceleration

The experimental data was measured to study the inter relationships among these variables

\section{EXPERIMENTAL WORK}

The experiments were conducted in an adjustable meandering rectangular flume of re-circulating type. Water was recirculating using an inline pump and the flow rate was measured by using precalibrated orifice meter. The tailgate at the downstream end of the flume was used ip control the depth of flow for each run. The dimensions of the tested meander: bed width $(B)=10,15,20 \mathrm{~cm}$, with bend radius $\left(\mathrm{r}_{\mathrm{c}}\right)=20,22.5$ and $25 \mathrm{~cm}$ respectively, the meander wave length, $(W)=66.6,75.0$ and $83.34 \mathrm{~cm}$ respectively, and the central bend angle $(\theta)=133.29^{\circ}$ for the tested models as shown in Figure (1). For all tested models the bed slope was kept horizontal and the two sides were vertical. To study the effect of curvilinear flow on scour depth, the bed wis covered initially by a uniform sand layer $20-\mathrm{cm}$ thick, and the $\mathrm{d}_{50}=0.22 \mathrm{~mm}$.

For each run the bed was leveled and the flow was passed through the flume by very low velocity to the required depth. After that the tail gate was opened gradually to give the suitable velocity which cause starting the scour process in bed material.

The maximum scour depth was measured at intervals of 15,30 and $60 \mathrm{~min}$ for each tested model by using the point gauge. The total number of runs were about 200 runs collected from the tested three models.

\section{ANALYSIS ANDDISCUSSION}

The relationships between the Froude's number at the center of cross section $\left(\mathrm{F}_{\mathrm{c}}\right)$ and the relative scour depth $\left(\mathrm{d}_{\mathrm{s}} / \mathrm{I}_{\mathrm{c}}\right)$ at different values of $\left(\mathrm{B} / \mathrm{r}_{\mathrm{c}}\right)$ for the upstream bend of the channel at different times at; $15,30^{\circ}$ and 60 minutes, are presented in Figures (2a, 2b and 2c). These figures show that the relative depth of scour " $\left(\mathrm{d}_{s} / \mathrm{H}_{\mathrm{c}}\right)$ increases by increasing the Froude's number at the center line $F_{c}$ for 
$\left(\mathrm{B} / \mathrm{r}_{\mathrm{c}}\right)=0.5,0.67$ and 0.80 . Also, the relationships show that for the same values of $F_{c}$, the relative scour depth $\left(d_{s} / H_{c}\right)$ increases by increasing the value of $\left(B / r_{c}\right)$ from 0.5 to 0.8 . This means that as the radius of curvature $\left(r_{c}\right)$ decreases the scour depth increases due to the increasing of the interaction between the secondary current and primary flow that produces a spiral flow pattern affecting the transport of sediments causing scour at the outer bank and deposition at the inner bank. The eddies cause scour depth near the outer side and deposition near the inner side, this results in larger transverse bed slope and therefore the larger particles of bed material can resist the transverse component of bed shear stress more than the finer particles. So, the fine particles are easily transported to the inner bank region as the transverse bed slope increases.

The relationships between the Froude's number at the center of cross section $\left(F_{c}\right)$ and the relative scour depth $\left(d_{s} / r_{c}\right)$ at different values of $\left(B / r_{c}\right)$ for the upstream bend of the channel at different times of 15,30 and $60 \mathrm{~min}$, are shown in Figures ( $3 a, 3 b$ and $3 c$ ). These Figures show that the relative depth of scour $\left(\mathrm{d}_{\mathrm{s}} / \mathrm{r}_{\mathrm{c}}\right)$ increases by increasing the Froude's number at the center line $\mathrm{F}_{\mathrm{c}}$ for $\mathrm{B} / \mathrm{r}_{\mathrm{c}}=0.50$, 0.67 and 0.80 . Also the relationships show that for the same values of $F_{c}$ the relative scour depth $\left(\mathrm{d}_{\mathrm{s}} / \mathrm{r}_{\mathrm{c}}\right)$ increases by increasing the value of $\left(B / r_{c}\right)$. This due to the increasing effects of spiral flow, which interacted with the secondary currents. The experimental results indicate that the maximum deposition height takes place between sections $30^{\circ}$ and $120^{\circ}$ and the maximum scour depth occurs between sections $10^{\circ}$ and $85^{\circ}$ for the upstream bend

Figures ( $4 a, 4 b$ and $4 c$ ) show the relationship between the Froude's number at the centerline of the downstream bend $\left(F_{c}\right)$ and the relative scour depth $\left(\mathrm{d}_{\mathrm{s}} / \mathrm{H}_{\mathrm{c}}\right)$ at different values of $B / r_{\mathfrak{c}}$ at different times 15,30 and $60 \mathrm{~min}$. These Figures show that the relative depth of scour $\left(\mathrm{d}_{\mathrm{s}} / \mathrm{H}_{\mathrm{c}}\right)$ increases by increasing the Froude's number at the centerline $F_{c}$ for $\left(B / r_{c}\right)=0.5,0.67$ and 0.80 . Also the relationships show that for the same values of $F_{c}$ the relative scour depth $\left(d_{s} / H_{c}\right)$ increases by increasing the value of $\left(\mathrm{B} / \mathrm{r}_{\mathrm{c}}\right)$ from 0.50 to 0.80 .

Figures (5a, $5 b$ and $5 c$ ) show the relationship between the Froude's number at the center of cross section $\left(F_{\mathfrak{c}}\right)$ and the relative scour depth $\left(d_{s} / r_{c}\right)$ at different values of $B / r_{c}$ for the downstream bend of the channel at different times 15,30 and 60 min. These figures show that the relative depth of scour $\left(d_{s} / r_{c}\right)$ increases by increasing the Froude's number at the centerline $\mathrm{F}_{\mathrm{c}}$ for $\mathrm{B} / \mathrm{r}_{\mathrm{c}}=0.5,0.67$ and 0.80 . Also the relationships show that for the 
same values of $F_{c}$ the relative scour depth $\left(d_{s} / r_{c}\right)$ increases by increasing the value of $\mathrm{B} / \mathrm{r}_{\mathrm{c}}$ from 0.50 to 0.80 . For the downstream bend the experimental results indicate that the maximum deposition height takes place between sections $40^{\circ}$ and $110^{\circ}$ and the maximum scour depth occurs between sections ${ }^{\prime} 0^{\circ}$ and $60^{\circ}$.

The relative scour depth $\left(d_{s} / H_{c}\right)$ for upstream bend at different values of $B / r_{c}$ $=0.5,0.67,0.80$, increases by increasing the time from $15 \mathrm{~min}$ to $60 \mathrm{~min}$. The rate of increasing in relative scour depth decreases by increasing $B / r_{c}$ from 0.50 to 0.80 as shown in Figures $(6 a, 6 b$, and $6 c)$.

Figure (7) shows the relationship between the measured and the calculated values of relative scour depth $\left(d_{s} / H_{c}\right)$ for all tested runs in the upstream bend. This figure shows that the measured values of $\left(\mathrm{d}_{\mathrm{s}} / \mathrm{H}_{\mathrm{c}}\right)$ are in good agreement with calculated values by using the following equation, which has been developec, by using multiple linear technique method.

$$
\begin{aligned}
& \frac{d_{s}}{H_{c}}=0.045+6.08 \frac{H_{c}}{r_{c}}+8.69 F_{c}^{0.1} \\
& -2.29\left(\frac{H_{c}}{B}\right)^{0.5}-4.26\left(\frac{H_{c}}{d_{50}}\right)^{0.1}+0.18 \frac{t}{t_{o}}
\end{aligned}
$$

Equation (2) has a regression coefficient $R^{2}$ $=0.77$, and the standard error of estimation $(\mathrm{S} . \mathrm{E} . \mathrm{E})=0.08$

Figure (8) shows the relationship between the measured and the calculated values of scour depth $\left(\mathrm{d}_{\mathrm{s}} / \mathrm{H}_{\mathrm{c}}\right)$ for all tested runs in the downstream bend. This figure shows that the measured values of $\left(\mathrm{d}_{s} / \mathrm{H}_{\mathrm{c}}\right)$ are in good agreement with calculated values by using the following equation, which has been developed, by using multiple linear technique method.

$$
\begin{aligned}
& \frac{d_{s}}{H_{c}}=0.803+7.0 \frac{H_{c}}{r_{c}}+9.05 F_{c}^{0.1} \\
& -3.51\left(\frac{H_{c}}{B}\right)^{0.5}-4.51\left(\frac{H_{c}}{d_{50}}\right)^{v .1}+0.127 \frac{t}{t_{o}}
\end{aligned}
$$

Equation (3) has a regression coefficient $R^{2}=0.82$, and the standard error of estimation (S.E.E) $=0.09$. Equations 2 and 3 can be used for estimating the maximum scour depth at the outer bank of upstream and downstream bend respectively within the following limits, $\mathrm{H}_{\mathrm{C}} / \mathrm{d}_{\mathrm{S}_{0}}=135-360$,

$$
\begin{aligned}
& \mathrm{d}_{50} / \mathrm{B}=1.10 \times 10^{-3}-2.2 \times 10^{-3}, \\
& \mathrm{~B} / \mathrm{r}_{\mathrm{C}}=0.50-0.80, \quad \mathrm{H}_{G} / \mathrm{B}=0.20-0.88, \\
& \mathrm{H}_{\mathrm{c}} / \mathrm{r}_{\mathrm{C}}=0.02-0.20 \text { and } \mathrm{F}_{\mathrm{c}}=0.15-0.45, \\
& \mathrm{t} / \mathrm{t}_{\mathrm{o}}=0.25-1.0
\end{aligned}
$$

Figures (9a and 9b) show the distribution of residuals values with the predicted values of $d_{s} / H_{c}$ for upstream bend and downstream bend respectively. The residuals are mostly distributed around the line of zero. Residuals with mean = $0.00165,-0.00292$, standard deviation S.D. $=0.054,0.069$, and correlation coefficient $\mathrm{r}$ $=-0.0139, \quad 0.028$ for upstream and downstream bend respectively. The low 
value of correlation coefficient means th: $x$ : the residuals are un-correlated indicating the validity of equations 2 and 3 for estimating the relative scour depth.

Figures (10) and (11) show the relationship between the measured and the calculated values of relative scour depth $\left(d_{s} / H_{c}\right)$ and the Froud's number $F c$ for all tested runs of upstream bend and downstream bend. These figures show that the relative scour depth for D.S. bend is bigger than of U.S. bend. This due to the effect of additional eddies and turbulence of coming curvilinear flow from upstream bend.

\section{Illustrative Example}

A rectangular open channel of two vertical sides has two successive bends of radius $20.0 \mathrm{~m}$ in opposite direction. The bed material has mean diameter $\mathrm{d}_{50}=1.10 \mathrm{~cm}$, the bed width of the channel is $10.0 \mathrm{~m}$. The water depth at centerline of the first bend is $2.0 \mathrm{~m}$ and the water depth at the centerline of second bend is $1.95 \mathrm{~m}$. If the discharge through the channel is $20 \mathrm{~m} 3 / \mathrm{s}$. Find the ultimate scour depth at the outer sides of the two bends for $t / t_{0}=1.0$.

\section{Given.}

$\mathrm{B}=10.0 \mathrm{~m}, \quad \mathrm{r}_{\mathrm{c}}=20 \mathrm{~m}$,

$\mathrm{H}_{\mathrm{c}}$ for U.S. bend $=2.0 \mathrm{~m}$, ,

$\mathrm{H}_{\mathrm{c}}$ for D.S. bend $=1.95 \mathrm{~m}$ $\mathrm{d}_{50}=1.10 \mathrm{~cm}, \quad \mathrm{Q}=20 \mathrm{~m} 3 / \mathrm{s}, \quad \mathrm{t} / \mathrm{t}_{0}=1.0$

Required: The maximum scour depth for upstream and downstream bend.

\section{Solution:}

\section{1- for upstream bend}

$F_{c}=\frac{V}{\sqrt{\mathrm{gH}_{\mathrm{c}}}}=\frac{(20 / 20)}{\sqrt{9.81 \times 2.0}}=0.226$

By using equation 2, then,

$$
\begin{aligned}
& \frac{d_{s}}{2.0}=0.045+6.08 \frac{2.0}{20}+8.69(0.226)^{0.1} \\
& -2.29\left(\frac{2.0}{10}\right)^{0.5}-4.26\left(\frac{2.0}{0.011}\right)^{0.1}+0.18(1.0) \\
& \therefore \mathrm{ds}=0.26 \mathrm{~m}
\end{aligned}
$$

\section{2- for downstream bend}

$F_{\mathrm{c}}=\frac{\mathrm{V}}{\sqrt{\mathrm{gH}_{\mathrm{c}}}}=\frac{(20 / 19.5)}{\sqrt{9.81 \times 1.95}}=0.235$

By using equation 3, then,

$$
\begin{aligned}
& \frac{d_{s}}{1.95}=0.803+7.0 \frac{1.95}{20}+9.05(0.235)^{0.1} \\
& -3.51\left(\frac{1.95}{10}\right)^{0.5}-4.51\left(\frac{1.95}{0.011}\right)^{0.1}+0.127(1.0) \\
& \therefore \quad \mathrm{ds}=0.63 \mathrm{~m}
\end{aligned}
$$

This example shows that the maximum scour depth at downstream bend is bigger than that of upstream bend due to the decrease of water depth at center line which cause increasing in Froude's number. Also the additional eddies of curvilinear flow from upstream to downstream bend causes increasing in scour depth. 


\section{CONCLUSIONS}

From the above discussion the following conclusions can be summarized.

- The relative scour depth $\left(\mathrm{d}_{s} / \mathrm{H}_{\mathrm{c}}\right)$ and $\left(\mathrm{d}_{\mathrm{s}} / \mathrm{r}_{\mathrm{c}}\right)$ increases by increasing the Froude's number $F_{c}$ at the centerline for $\mathrm{B} / \mathrm{r}_{\mathrm{c}}=0.5,0.67$ ard 0.80 . Also for constant values of $F_{c}$ the relative scour depth $\mathrm{d}_{s} / \mathrm{H}_{\mathrm{c}}$ and $\left(\mathrm{d}_{\mathrm{s}} / \mathrm{r}_{\mathrm{c}}\right)$ increases by increasing the value of $\mathrm{B} / \mathrm{r}_{\mathrm{c}}$.

- When the radius of curved channel $r_{c}$ decreases the scour depth increases due to the major effect of crowded curvilinear streamlines, which produces a spiral flow and eddy currents that cause scour at the outer bank and deposition at the inner bank

- Empirical equations 2 and 3 alle developed for estimating the relative scour depth for upstream and downstream bend respectively as a function of $\mathrm{H}_{\mathrm{c}} / \mathrm{r}_{\mathrm{c}}, \mathrm{F}_{\mathrm{c}}, \mathrm{H}_{\mathrm{c}} / \mathrm{B}, \mathrm{H}_{\mathrm{c}} / \mathrm{d}_{50}$ and $t / t_{0}$.

- The maximum scour depth at the outer side of downstream bend is bigger than that of upstream bend due to the additional eddy currents and turbulence of curvilinear flow which coming from the upstream bend.

- The rate of increasing in relative scour depth decreases by increasing $R$ from 0.50 to 0.80 .
- The increasing of streamline curvature at the outer side of the bend and the formation of soncentrated helical flow, cause the scour in bed material at the outer bank region. Therefore in order to prevent the scour at the outer side, protective structures such as diagonal sills which can be installed on the bottom of the channel near the ends of bends to reduce the disturbance of flow at the outer side.

\section{REFERENCES}

1- Carson, M. A., and LaPointe,M. F., (1983), "Inherent asymmetry of river meander plan form", J. of Geology, Vol,91, pp.41-55.

2- Engelund, F. (1974), "Flow and bed topography in channel bends", J. of hyd. Div. ASCE, Vol. 100, No.11, Nov. 1974, pp1631-1648.

3- Hooke, R.L.(1974), "Distribution of sediment and Shear stress in a meander bend", Journal of Geology, Vol.83,1975,pp. 543-567.

4- Ikeda, S. Yamasaka, M., and Chiyoda, M. (1987), " Bed topography and sorting in bends", J. of Hyd. Eng., ASCE113 (2), pp. 190-206.

5- Kâyai , S. and Julien, P.Y.(1996), "Point bar deposits in narrow" sharp bends", J. of Hyd. Res., Vol.34, No. 2, pp. 205-218. 
6- Kikkawa H., Ikeda S. and Kitagawa

A. (1976), "Flow and bed topography in curved open channels", ASCE. J. Hyd. Div. Vol.102 pp.1327-1342.

7- Odgaard,A. J. (1987), " Stream-bank erosion along two rivers in Iowa.", Water Res., 23(7), 1225-1236.

8- Struiksma, N., Olesen, K. W., Flokstra, C. and De Vriend (1985),"“ Bed deformation in curved alluvial channels", J. of Hyd. Res. Vol. 23 No.1, pp. 57-79.

9- Yen C. L. (1970), "Bed topography effect on flow in a meander". ASCE., Vol. 96, No. HY1. pp. 57-73.

10- Yen, C. L. and Lee, K.T. (1995), "Bed Topography and sediment sorting in channel bends with unsteady flow", J. of Hyd. Eng. ASCE., Vol. 121, No.
8. pp. 591-599.

\section{NOMENCLATURES}

B : the channel width

$\mathrm{d}_{s}$ : the maximum depth of scour

$\mathrm{d}_{50}:$ mean diameter of bed material

$F_{c}:$ the Froude numb $\therefore$ at the center line

$\left(=\mathrm{Vc} / \sqrt{\mathrm{gH}_{\mathrm{c}}}\right)$

$\mathrm{g}$ : gravitational acceleration

$\mathrm{H}_{\mathrm{c}}$ : water depth at center line of the curved channel

$r_{c}$ : radius of curved channel at the center line

$t$ : time of scour.

$t_{0}$ : time of ultimate scour depth

$\mathrm{V}$ : the mean velocity.

$\mathrm{W}$ : the meander wave length

$\theta:$ the central bend angle.

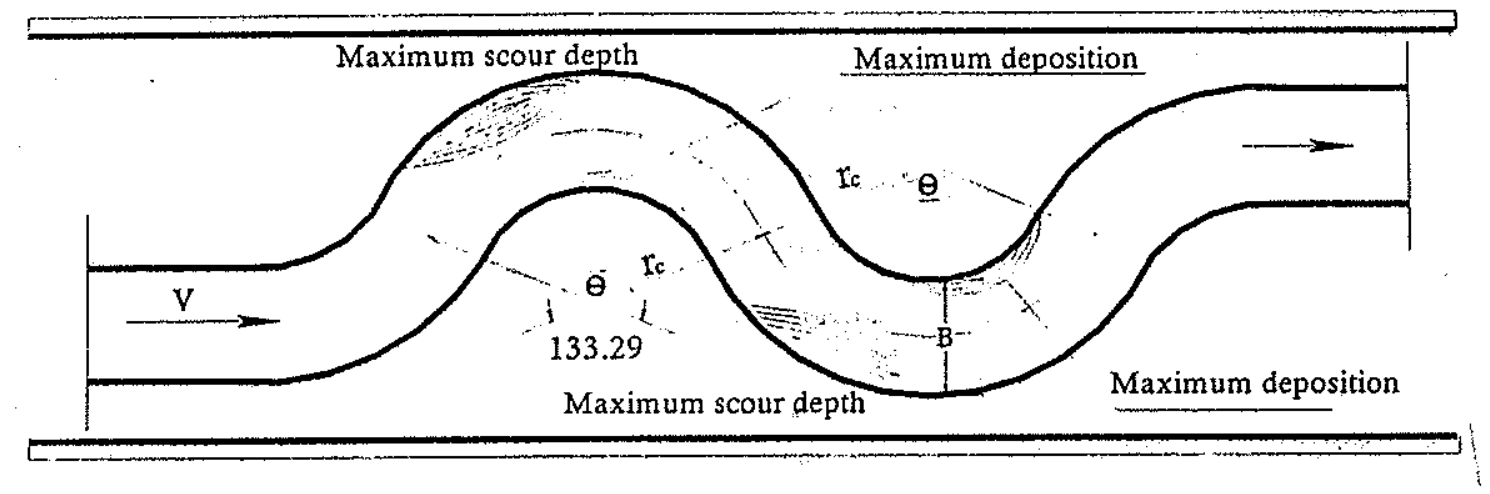

FIG.(1) DEFINITION SKETCH 


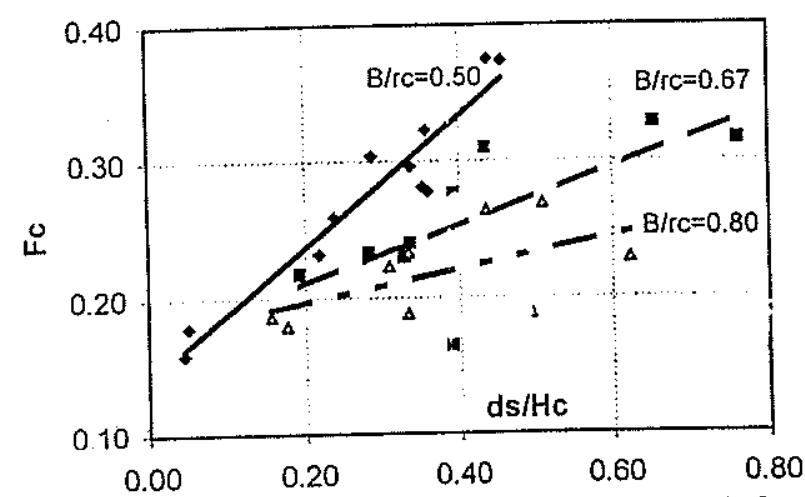

Fig. (2a) The relation between Fc and ds/Hc for upstream bend at time $=15 \mathrm{~min}$.

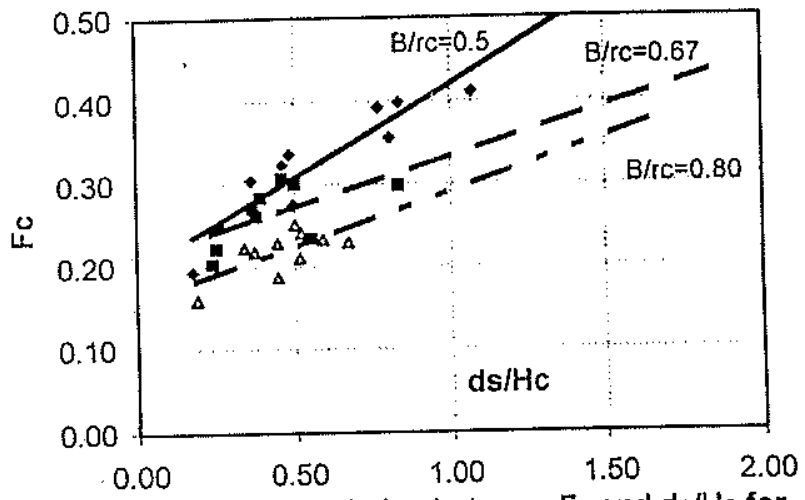

Fig. (2b) The relation between $F c$ and ds/Hc for upstream bend at time $=30 \mathrm{~min}$.

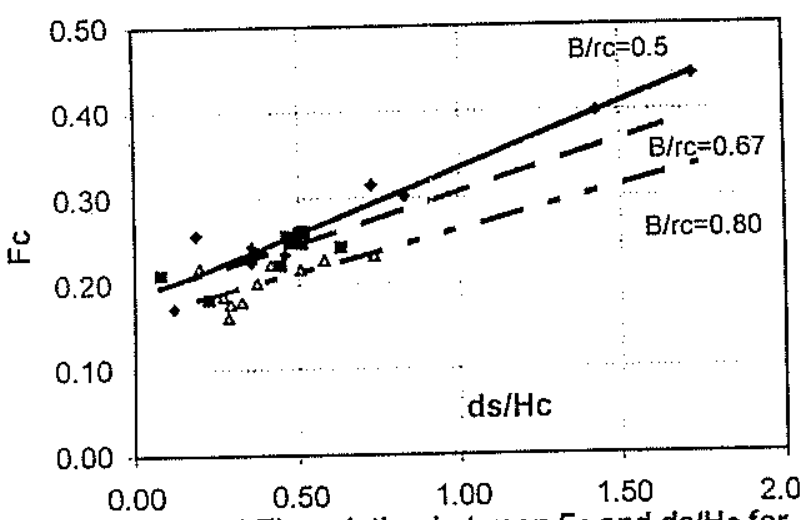

Fig. (2c) The relation between $\mathrm{Fc}$ and $\mathrm{ds} / \mathrm{Hc}$ for upstream bend at time $=60 \mathrm{~min}$.

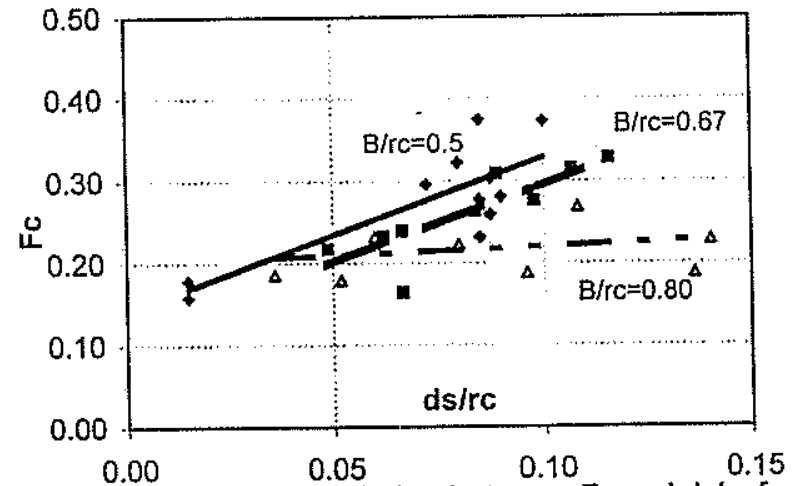

Fig. (3a) The relation between Fc and ds/rc for upstream bend at time $=15 \mathrm{~min}$.

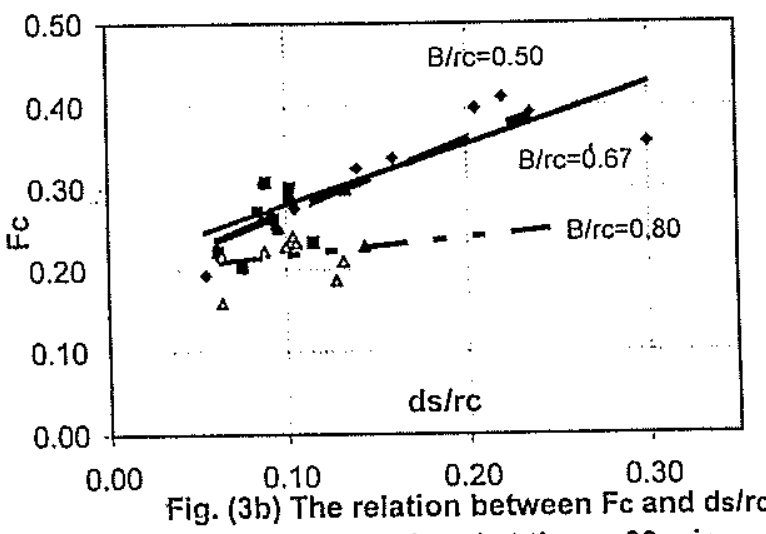

for upstream bend at time $=30 \mathrm{~min}$.

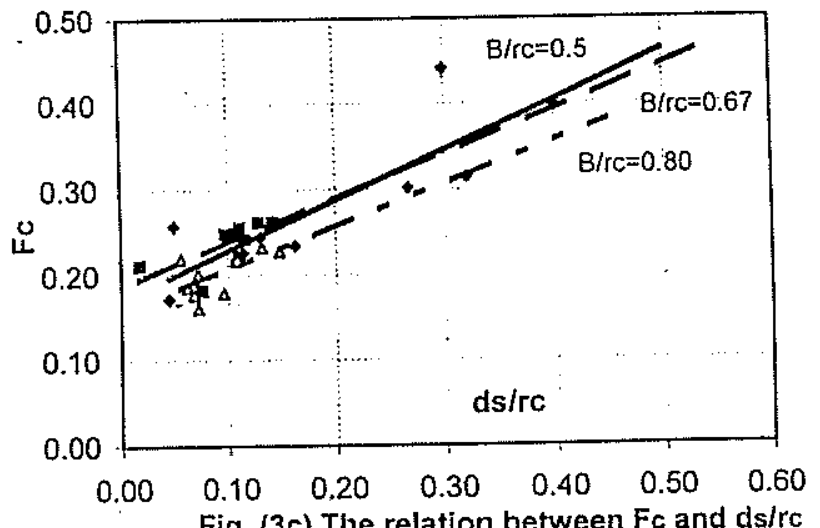

Fig. (3c) The relation between $F c$ and ds/rc for upstream bend at time $=60 \mathrm{~min}$. 


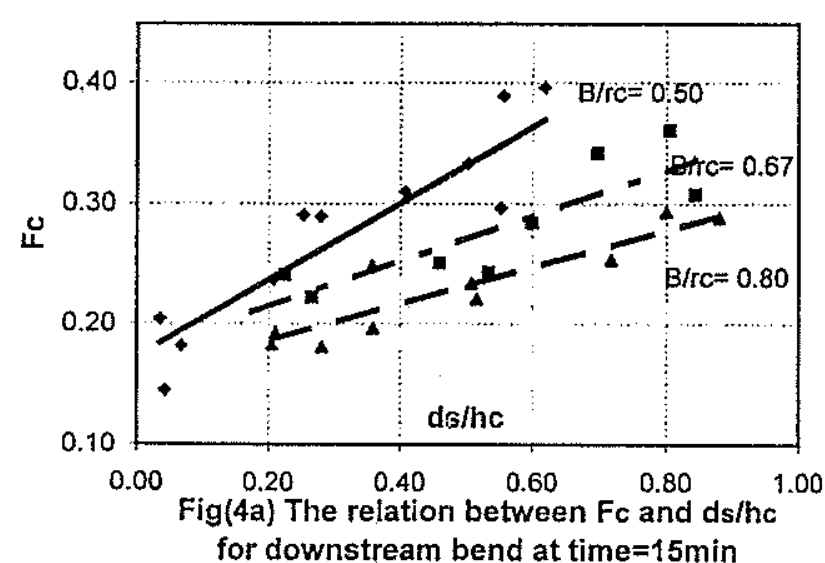

for downstream bend at time $=15 \mathrm{~min}$

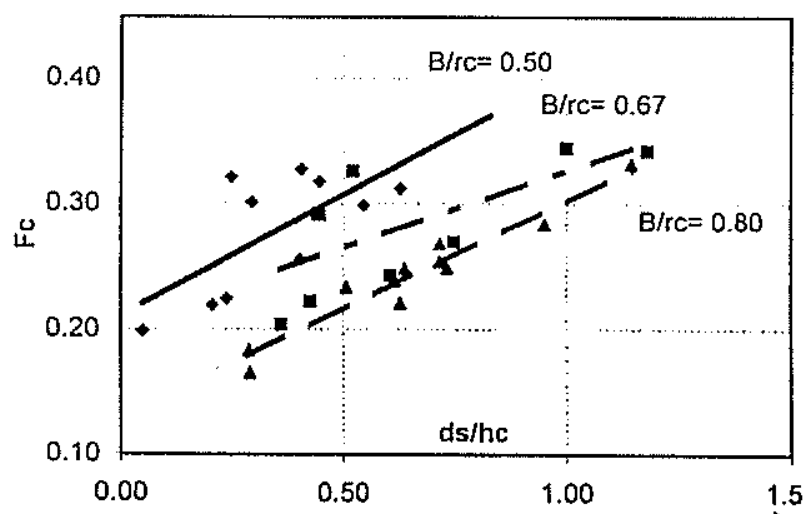

Fig(4b) The relation between $\mathrm{Fc}$ and $\mathrm{ds} / \mathrm{hc}$ ' for downstream bend at time $=30 \mathrm{~min}$

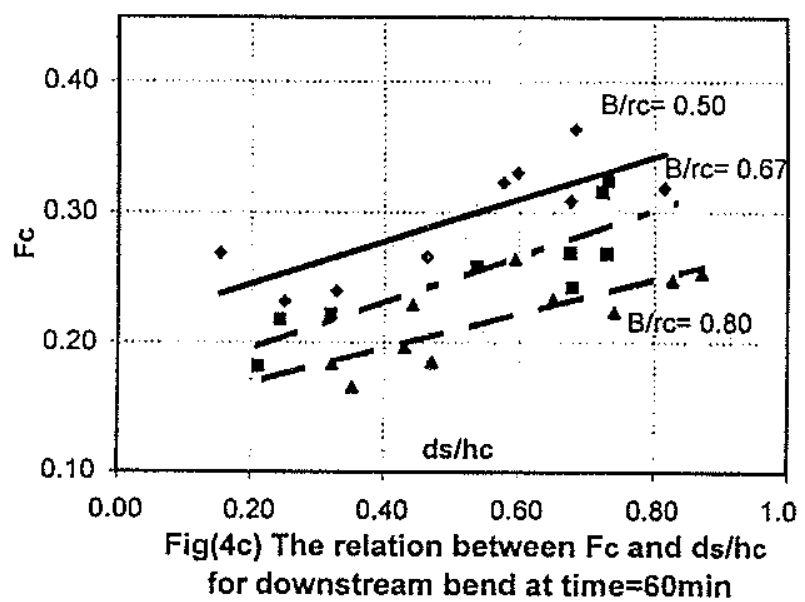

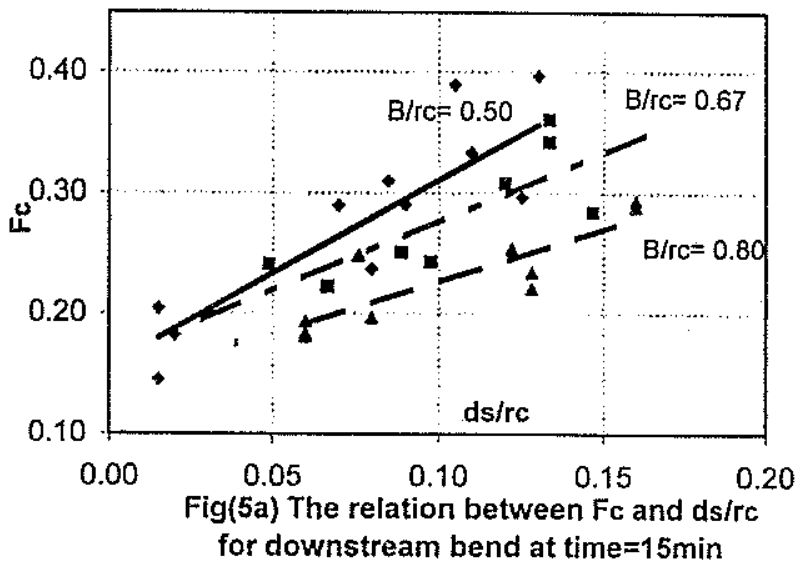
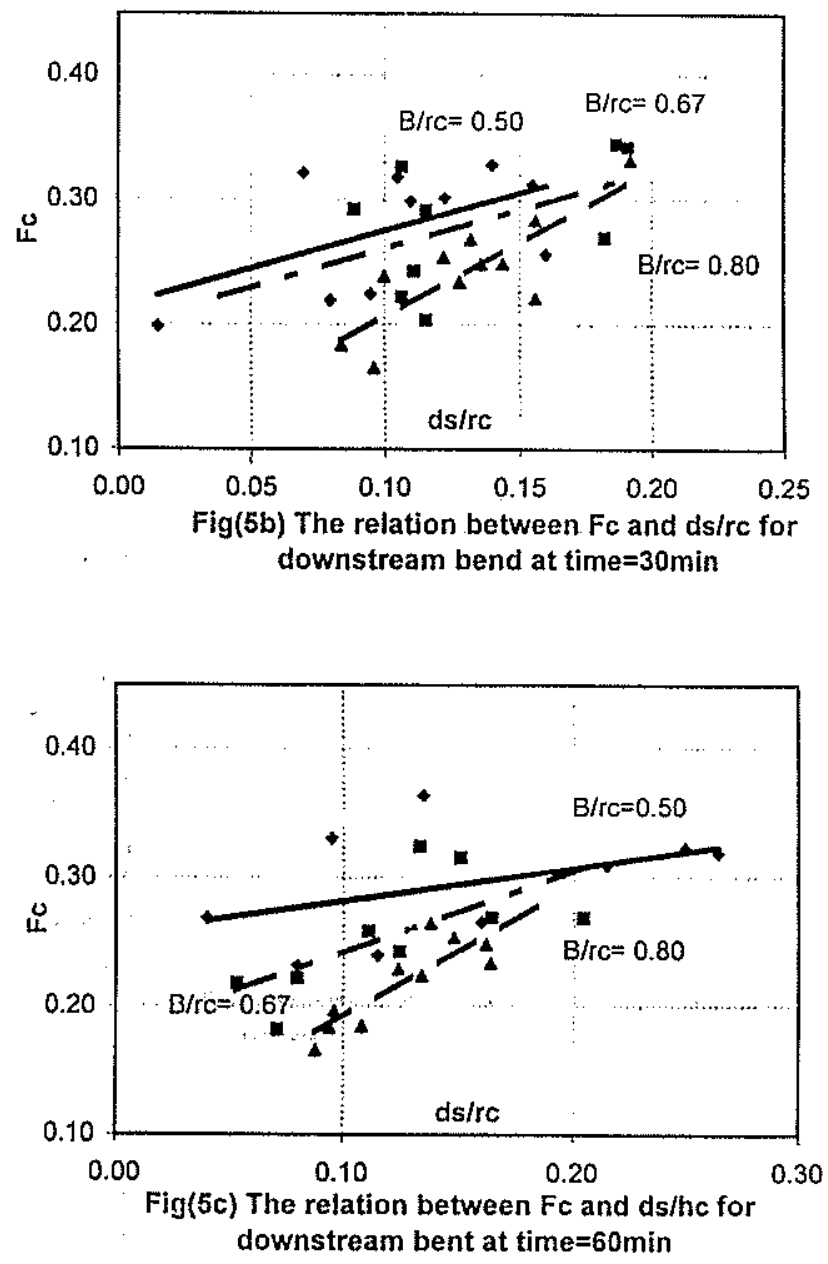


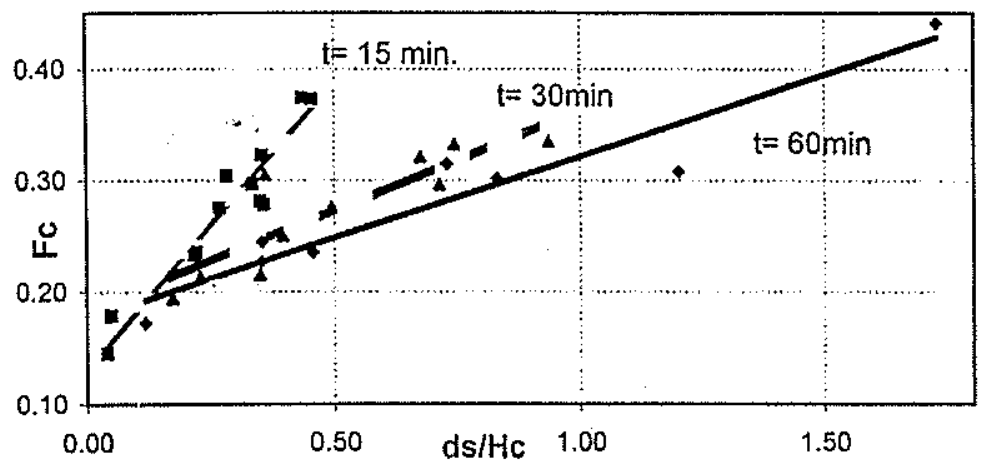

Fig. (6a) The relation between $\mathrm{Fc}$ and $\mathrm{ds} / \mathrm{Hc}$ for $\mathrm{B} / \mathrm{rc}=0.5$ at different times for U.S. bend.

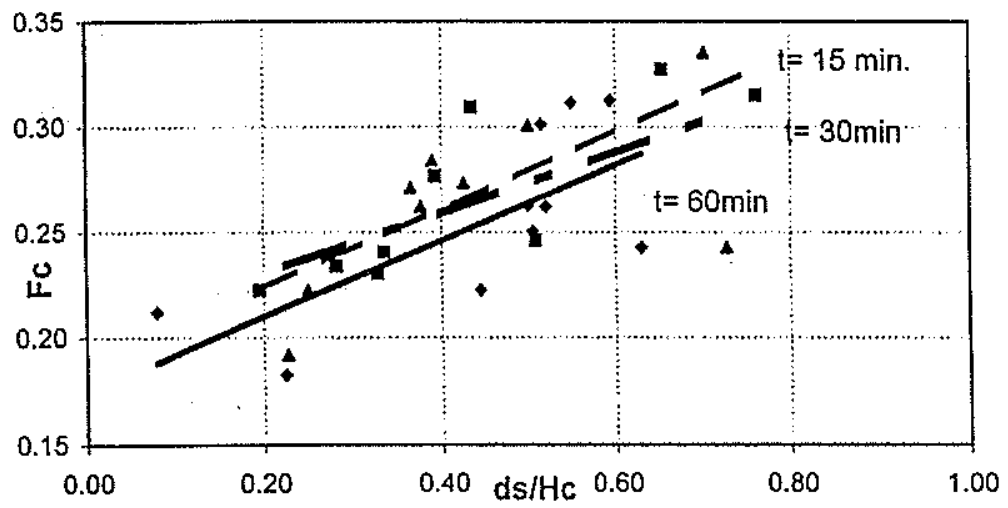

Fig. (6b) The relation between Fc and ds/Hc for $B / r c=0.67$ at different times for U.S. bend.

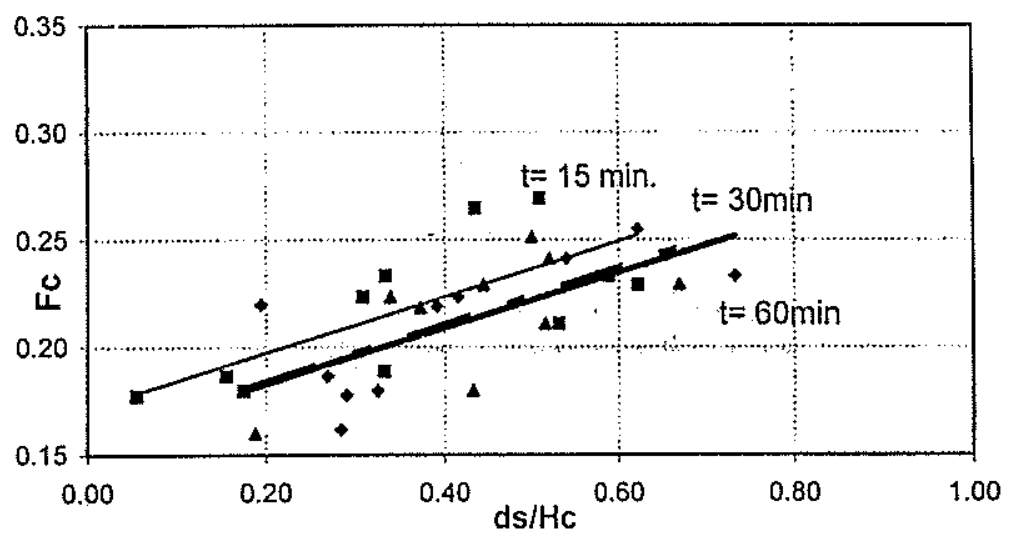

Fig. (6c) The relation between $\mathrm{Fc}$ and $\mathrm{ds} / \mathrm{Hc}$ for $\mathrm{B} / \mathrm{rC}=0.80$ at different times for U.S. bend. 


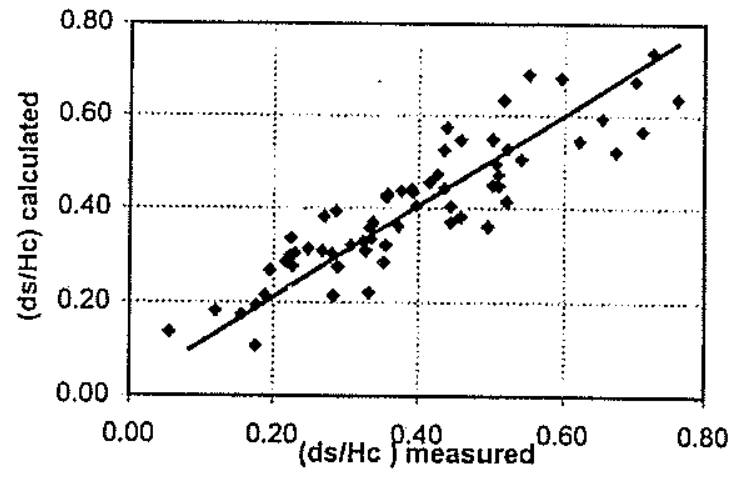

Fig.(7) The relationship between the meastured and the calculated values of ds/Hc for U.S bend

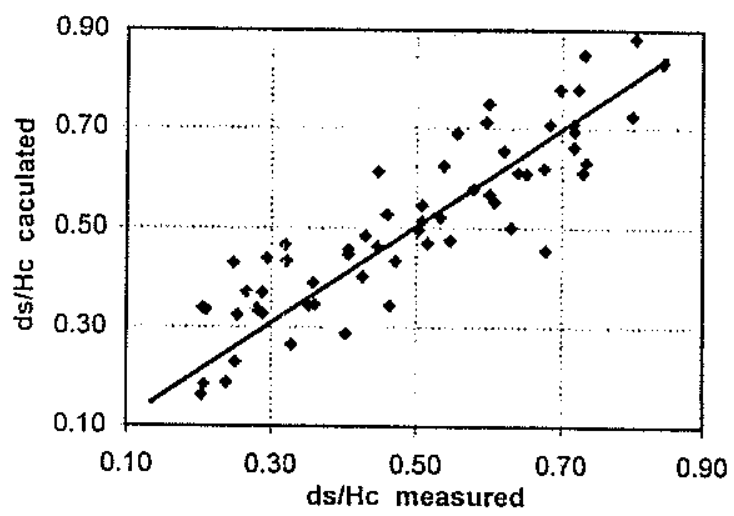

Fig.(8) The relationship between the measured and the calculated values of ds/HC for D.S bend

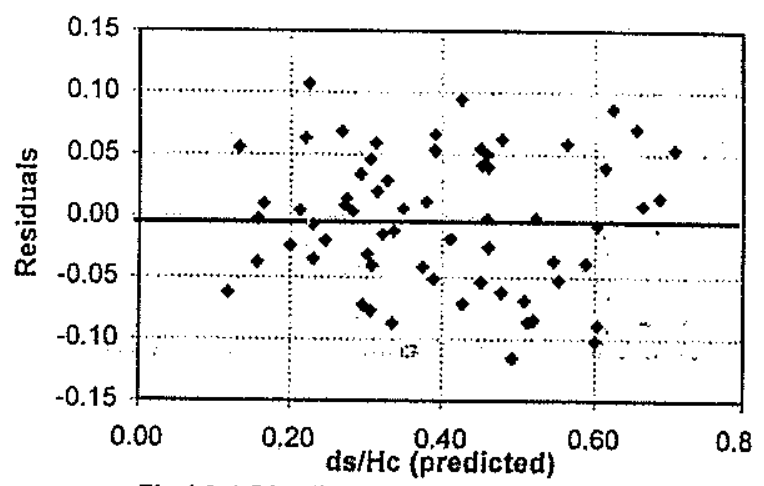

Fig.( 9a) Distribution of residuals with the predicted values of ds/Hc for U.S: bend

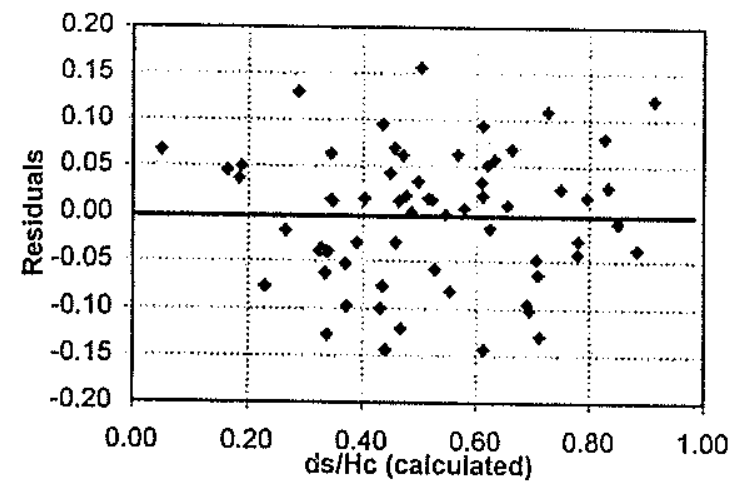

Fig.(9b) Distribution of residuals with the predicted values of ds/Hc for D.S. bend

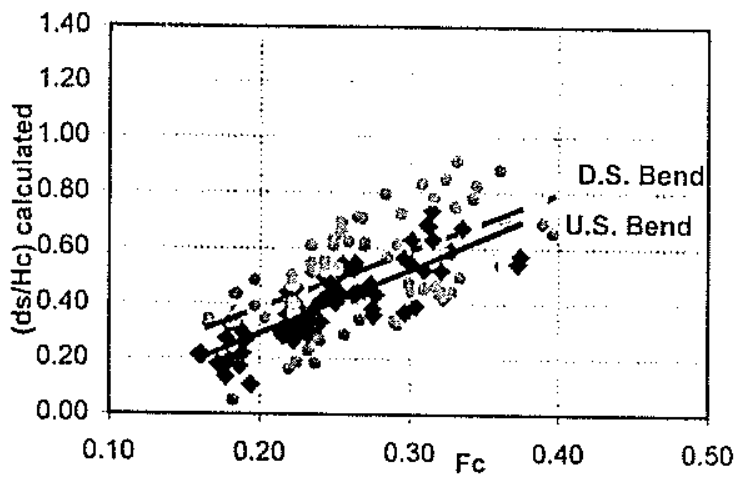

Fig.(10) The relationship between the calculated values of (ds/Hc) and $\mathrm{Fc}$

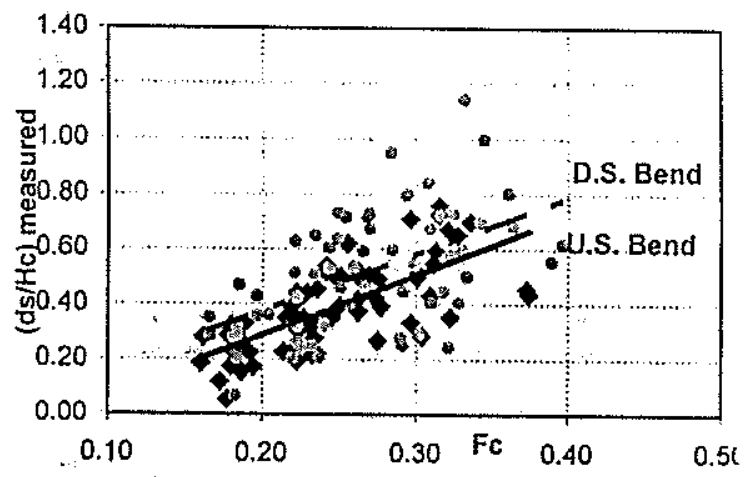

Fig.(11) The relationship between the measured values of (ds/Hc) and $\mathrm{Fc}$ 